\title{
LEGAL PROTECTION TOWARDS EXPORTERS AND IMPORTERS IN INTERNATIONAL TRADE TRANSACTIONS USING LETTER OF CREDIT (L/C) AS A PAYMENT SYSTEM AT PT. BANK MAYBANK INDONESIA TBK BRANCH OF BENGKULU
}

By :

Dinda Estasari, Widiya N. Rosari, Tito Sofyan

\begin{abstract}
This study aims to examine and to analyze the legal protection of exporters and importers in international trade transactions using Letter of Credit $(\mathrm{L} / \mathrm{C})$ as a payment system at PT. Bank Maybank Indonesia Tbk branch of Bengkulu. The type of this study was normative legal research with descriptive analytical research design. The result of this study indicated that in an international payment system that used L/C, both exporters and importers were protected, thus exporters did not have to worry about their goods not being paid for, while importers did not need to worry that the goods they bought did not arrive or that they would lose payment, because the bank would guarantee this matters if the required documents were appropriate. PT. Bank Maybank Indonesia Tbk branch of Bengkulu, in protecting its customers, must have considerations both based on the provisions of national banking regulations and based on the applicable banking practices. The efforts made by banks to protect exporters and importers were such as banks have to implement good corporate governance, apply Know Your Customer principles including the principle of prudence in providing $\mathrm{L} / \mathrm{C}$ facilities, apply the Know Your Employee principle. Moreover, it was necessary to apply optimal sanctions in case of violation of procedures. The L/C arrangements at PT. Bank Maybank Indonesia Tbk branch of Bengkulu adheres to UCP 600 so that it can avoid differences or misinterpretation between the transacting parties as far as possible.
\end{abstract}

\section{Keywords : Legal Protection, Letter of Credit (L/C), International Trade, International Payment Systems}




\section{A. INTRODUCTION}

The rapid development in the business sector in terms of technology, communication and transportation has had a major impact on increasing trade activities between countries. Trade transaction on an international scale, better known as exportimport, is essentially a simple transaction and are nothing more than buying and selling goods between entrepreneurs who are located in different countries. In many branches of trade and companies, for a long time there were more agreements than laws, because

most of them were not guided by statutory regulations, but rather to the contract model. ${ }^{1}$

The principle of freedom of contract is a principle which states that basically, everyone is allowed to make a contract (agreement) which contains any kind of matters as long as it does not contradict the law, morals and public order. Every legal system in the world recognizes and respects this fundamental principle. Traders or

\footnotetext{
${ }^{1}$ LJ Van Apelderon, Pengantar Ilmu Hukum,
} Pradnya Paramitha, Jakarta, 1990, p. 158. entrepreneurs anywhere and under any legal system are guaranteed the freedom to make contracts. ${ }^{2}$

One of the payment systems used by exporters and importers in international trade

transactions is a Letter of Credit. Letter of Credit, which is commonly abbreviated as $\mathrm{L} / \mathrm{C}$ in Indonesian, is referred to as a Documeneted Letter of Credit. L/C is one of the bank services provided to the public to facilitate the flow of goods (export-import) including domestic goods (inter- islands). In general, a letter of credit is a statement from the bank at the request of the customer (usually the importer) to provide and to pay a certain amount of money for the benefit of a third party (L/C recipient or exporter). ${ }^{3}$ The $\mathrm{L} / \mathrm{C}$ is issued to realize the basic contract, the $\mathrm{L} / \mathrm{C}$ is a payment contract while the base contract is a sales contract. ${ }^{4}$

The legal basis for $\mathrm{L} / \mathrm{C}$ in Indonesia is Government

\footnotetext{
${ }^{2}$ Huala Adolf, Dasar-Dasar Hukum Kontrak Internasional, Refika Aditama, Bandung 2008, p. 20.

${ }^{3}$ Kasmir, Bank dan lembaga Keuangan Lainnya, Rajawali Pers, Jakarta, 2013, p. 142.
} 
Regulation No. 1 of 1982 , but it does not contain details regarding L/C. In banking practice in Indonesia, many parties use the $\mathrm{UCP}$ as an L/C provision. Bank Indonesia supports that all $\mathrm{L} / \mathrm{C}$ issued by commercial banks comply with the UCP. Bank Indonesia sees that a sense of security is created if $\mathrm{L} / \mathrm{C}$ complies with the UCP. Bank Indonesia in Circular Letter No. 26/34/ULN dated on $17^{\text {th }}$ of December 1993 stipulated that $\mathrm{L} / \mathrm{C}$ issued by foreign exchange banks may or may not comply with the UCP. Bank Indonesia in formal juridical terms gives freedom to foreign exchange banks in Indonesia to determine their attitude. ${ }^{5}$

The L/C payment system also has several weaknesses, namely the possibility of a violation committed by one of the parties, where the other party will have their rights violated for this transaction and provide opportunities for parties with bad faith to commit fraud in $\mathrm{L} C \mathrm{C}$

${ }^{4}$ Ramlan Ginting, Letter of Credit Tinjauan Aspek Hukum \& Bisnis, Publisher Trisakti University, Jakarta, 2015, p. 16.

${ }^{5}$ Soepriyo Andhibroto, Letter of Credit: Dalam Teori dan Praktek, Dahara Prize, Semarang, 1992, p. 8 transactions. The opportunity in question can be used by the buyer in collaboration with the seller, or the seller in collaboration with the appointed bank or the seller himself.

Seeing these weaknesses both in the process and legal rules governing the $\mathrm{L} / \mathrm{C}$, the writer was interested in discussing this issue in the form of a Thesis entitled "Legal Protection Towards Exporters and Importers in International Trade Transactions Using Letter of Credit (L/C) as a Payment System at PT. Bank Maybank Indonesia Tbk Branch of Bengkulu".

\section{Identification of the problem}

How was the legal protection for exporters and importers in international trade transactions using $\mathrm{L} / \mathrm{C}$ as a payment system at PT. Bank Maybank Indonesia Tbk Branch of Bengkulu?

\section{B. RESEARCH METHODS}

This study was a legal research with the type of Normative Legal Research. This study described the legal protection of exporters and importers in international trade 
transactions using $\mathrm{L} / \mathrm{C}$ as a payment system at $P T$. Bank Maybank Indonesia Tbk Branch of Bengkulu. Primary legal materials were obtained from various statutory regulations, while secondary legal materials came from books, journals, and articles both from online and offline media related to $\mathrm{L} / \mathrm{C}$, as well as gotten through literature study techniques coupled with interviews with the PT. Bank Maybank Indonesia Tbk. Then the data were processed and analyzed by using qualitative analysis methods.

\section{RESEARCH RESULTS AND}

\section{DISCUSSION}

Legal protection for
exporters and importers in
international trade transactions
using L / C as a payment
system at PT. Bank Maybank

Indonesia Tbk Branch of Bengkulu.

M. Hadjon stated that there are two forms of legal protection, namely: Preventive dan Repressive. Preventive protection functions to prevent losses, while repressive legal protection is provided when losses have occurred. Preventive legal protection can be provided to parties to prevent losses that can be experienced by the parties involved in the agreement, while repressive legal protection is provided when losses have occurred $^{6}$.

The Civil Code has stipulated in Article 1338 that all agreements made legally have the same power as the law for both parties. Therefore, it is clearly stipulated in the laws and regulations that the agreement that has been agreed by the parties must be carried out accordingly. If there is a party who feels aggrieved because the other party in the agreement does not carry out their achievements, they can process the problem through litigation to get legal protection. In filing a lawsuit in court, strong evidence is needed to support the ongoing legal process ${ }^{7}$.

In the issuance of $\mathrm{L} / \mathrm{C}$, the parties, both the customer and the issuing bank, may suffer losses if one of the parties violates or does not implement the provisions contained in the agreement. This can cause a large amount of loss.

\footnotetext{
${ }^{6}$ Philipus.M. Hadjon. Perlindungan Hukum bagi Rakyat di Indonesia. Bina Ilmu, Surabaya, 1987, p. 38.

${ }^{7}$ Ibid p. 39.
} 
To bridge the interests of the exporter so that the goods are sent after the price is paid, while the importer has an interest that the price is paid after the goods are received, a payment system using $\mathrm{L} / \mathrm{C}$ is used. In this case, a payment is made through the bank as an intermediary, without first waiting for the goods or the documents to arrive. This obligation is carried out with the obligation of the importer to open an L / C at a bank in the importer country, which is then forwarded by the bank to the bank in the exporting country ${ }^{8}$.

System payment by $\mathrm{L} / \mathrm{C}$ is now widely accepted among international trade traffic. International trade transactions with a payment system that includes several methods will facilitate implementation in this international business, because each party no longer needs to hold face-to-face talks, but only selects available payment methods.

\section{Legal Protection for Exporters in the Use of $\mathrm{L} / \mathrm{C}$}

In connection with the issue of

\footnotetext{
${ }^{8}$ Sarah Di Roero, Perlindungan Terhadap Bank Dalam Transaksi Perdagangan Dengan Menggunakan Sarana Letter of Credit, Scientific Journal, Samratulangi University, Manado, 2013, p. 29.
}

legal protection for exporters, the use of $\mathrm{L} / \mathrm{C}$ as a payment instrument in international trade transactions can be seen from the extent of the advantages of $\mathrm{L} / \mathrm{C}$ that can be enjoyed by the exporter. The advantages of $\mathrm{L} / \mathrm{C}$ for exporters can be stated as follows ${ }^{9}$ :

1) Payment Certainty and Avoiding Risk.

Even though the exporter does not know the importer, the existence of an $\mathrm{L} / \mathrm{C}$ is a guarantee for the exporter that the bank must pay the bill according to the provisions. The reputation or the good name of the bank that opens the $\mathrm{L} / \mathrm{C}$ is the principal guarantee, and the payment guarantee will be doubled if the foreign exchange bank acting as the Advising Bank also provides confirmation. So the risk of not getting paid is minimal. This shows the large role of banks in facilitating international trade.

2) Document Can Be Cashed Immediately.

When the goods have been shipped, then with the existence of L/C, shipping documents can be

\footnotetext{
9 Amir, MS, Kontrak Dagang Ekspor, PPM

Publisher, Jakarta, 2002, p. 5.
} 
cashed directly or negotiated with the Advising Bank and there is no need to wait for payment or remittances from the importer. The Advising Bank or Negotiating Bank does not hesitate to pay off the shipping documents because the payment is guaranteed by the Opening Bank. On the other hand, if there is no $\mathrm{L} / \mathrm{C}$, it is impossible for the exporter to negotiate shipping documents, so he must wait for the transfer or remittance of money in advance from the importer, or the documents must be sent first for "Collection".

3) Avoid the Risk of Currency Transfer Restrictions.

In various countries there are restrictions on foreign currency transfers and an import permit is required before opening an L / C. Foreign exchange banks in importing countries already know about this provision and they are only willingopen an L / C if all the provisions of the Government have been fulfilled by the importer. Therefore, at every L / C opening the Bank has provided foreign currency for each bill based on the L / C. Thus, exporters are protected from non- payment risks that may occur if transactions are carried out without L / C.
4) The Possibility of Getting a

Down Payment or Interest-free Credit

If the importer is willing to open an L/C with "Red Clause" terms, then the exporter can get an advance from the $\mathrm{L} / \mathrm{C}$ that is available. This means that the exporter receives interest-free credit or a kind of down payment that is usually required to start production of the goods to be exported.

\section{Legal Protection for Importers in the Use of $\mathrm{L} / \mathrm{C}$}

With regard to legal protection for importers, it can be seen the advantages of using $\mathrm{L} / \mathrm{C}$ for importers, which can be stated as follows ${ }^{10}$ :

1) Opening $\mathrm{L} / \mathrm{C}$ means that Opening Bank lends its good name and reputation to importers so that it can be trusted by exporters. The exporter is sure that the goods to be delivered will definitely be paid for.

2) The $L / C$ is a guarantee for the importer that the documents for the goods ordered will be received in a complete and intact condition, because it

${ }^{10}$ Ibid. 
will be examined by a bank that has expertise in that field.

3) The importer can state the requirements for safeguards which the exporter will obey in order to withdraw money from the available $\mathrm{L} / \mathrm{C}$.

\section{Protection toward Exporters} and Importers in the $\mathrm{L} / \mathrm{C}$ Payment System at PT Bank Maybank Indonesia Branch of

\section{Bengkulu}

In implementing LC, the bank only deals with documents. If the documents received by the bank do not contain discrepancies and are in accordance with the terms of the LC, the bank must pay the $\mathrm{LC}$ according to the UCP rules. In Article 5 of UCP 600 , it is stated that the banks deal with documents and not with goods, services or performances to which the documents may relate. This clause can be interpreted that the bank only deals with documents, not with goods, services or work performance related to these documents. This shows that all banks only refer to documents in their involvement as an intermediary in international business transactions.

One of the cases of protection for L/C importers at PT Bank Maybank Indonesia Tbk is a case where the documents required in the $\mathrm{L} / \mathrm{C}$ are not exactly the same as the documents submitted by the exporter or there are irregularities, the goods sent should have been obtained first. certificate of weight but the document cannot be completed by the exporter, then PT Bank Maybank Indonesia Tbk immediately postpones payment and returns the document to the exporter to be completed, because for some reason the exporter cannot complete the requested document, the bank suggests or requests that the exporter immediately contact the importer to make changes or amendments to the terms of the L/C to match the conditions of the exporter's documents. ${ }^{11}$

Based on the results of the researcher interview with $\mathrm{Mr}$. Fajri, he explained that Maybank as an L/C paying bank to avoid the risk of fraud, is very careful in accepting customers who will apply for $\mathrm{L} / \mathrm{C}$, customers must have gone through the know your customer process at PT Bank Maybank Indonesia, must have Trade checking is good, the export destination country is also

\footnotetext{
${ }^{11}$ Interview with Meiria Putri Alsa, Trade Finacing Division, at PT. Bank Maybank Indonesia Tbk

Bengkulu Branch, June 22, 2020 at 5 pm.
} 
not allowed if the country is in the high risk category, and there must also be trade checking for importers through the $\mathrm{L} / \mathrm{C}$ issuing bank, and the L/C issued must comply with UCP 600 with irrevocable $\mathrm{L} / \mathrm{C}$ conditions. This is very useful to protect the parties in an $\mathrm{L} / \mathrm{C}$ payment transaction. ${ }^{12}$

Form of Protection of PT Bank Maybank Indonesia Tbk Branch of Bengkulu as the Issuing Bank for avoiding L/C fraud, including the implementation of good corporate governance, the application of the Know Your Customer principle (the principle of prudence in the provision of $\mathrm{L} / \mathrm{C}$ facilities), the application of the Know Your Employee principle, the application of optimal sanctions in the event of misuse of procedures in opening L/C. The implementation of these matters is very important to guard against the emergence of malicious motives that will harm the parties through L/C transactions, namely by understanding the flow of transactions from issuance to settlement of L/C transactions. ${ }^{13}$

\footnotetext{
${ }^{12}$ Interview with Mr. Fajri, Head of Trade Stores, PT. Bank Maybank Indonesia Tbk Bengkulu Branch, April 13, 2020, at 5.30 pm.

${ }^{13}$ Sarah DI Roeroe, op cit p. 31
}

The Bank interprets the principle of prudence as an effort to anticipate the emergence of a risk that could harm the bank. Before issuing an L/C, a Bank must apply the Prudential Principle by using the Debtor analysis action in the form of the $5 \mathrm{C}$ principle, which includes character analysis, capability analysis, capital analysis, collateral analysis, and business condition analysis. ${ }^{14}$ So that the issuing bank can assess the financial capacity of the debtor in fulfilling his payment obligations to the Beneficiary and to the Issuing Bank.

UCP 600 does not regulate the precautionary principle, so the implementation of the prudential principle implemented by the Bank is based on Act Number 7 of 1992 concerning Banking as amended by Act Number 10 of 1998 and Bank Indonesia Regulation Number: 7/4/PBI/2005 concerning Prudential Principles in Asset Securitization Activities for Commercial Banks ${ }^{15}$ In connection

\footnotetext{
${ }^{14}$ Lukmanul Hakim, Prinsip Kehati-hatian pada Lembaga Perbankan Dalam Pemberian Kredit, Scientific Journal, Bandar Lampung University, Bandar Lampung, 2018, p. 21

15 Uswatun Hasanah, Perlindungan Hukum Nasabah, Filosofi, teori dan Konstruksi,
} 
with the absence of regulations that specifically regulate the principle of prudence and the issuance of $\mathrm{L} / \mathrm{Cs}$, the $\mathrm{L} / \mathrm{C}$ agreement must state that this $\mathrm{L} / \mathrm{C}$ is subject to UCP 600 , the Banking Law, PBI Prudential Principles and all regulations. What is there now, or that will exist later, or that will be enforced, also applies to this agreement.

One example of the form of bank protection in the payment of Import L/C that has occurred at PT. Bank Maybank Indonesia is a request for postponement of payment made by buyers in Bengkulu because the quantity of goods exported (asphalt) does not match the quantity in the $\mathrm{L} / \mathrm{C}$, but according to article 5 in the UCP mentioned earlier, that the bank only deals with the documents not on the quantity of goods received, the maybank as the $\mathrm{L} / \mathrm{C}$ issuing bank will continue to disburse the $\mathrm{L} / \mathrm{C}$ to the paying bank to be paid to the exporter, because after checking the documents are in accordance with

those in the L/C. The buyer can ask for compensation from the insurance company for the shortage of the goods received because there has been a depreciation during the delivery process. ${ }^{16}$

\section{CLOSING}

\section{Conclusion}

Export-import transactions are carried out through the use of $\mathrm{L} / \mathrm{C}$ instruments, thus both exporters and importers were protected, thus exporters did not have to worry about their goods not being paid for, while importers did not need to worry that the goods they bought did not arrive or that they would lose payment, because the bank would guarantee this matters if the required documents were appropriate.Banks as a third party must have considerations based on the provisions of national banking regulations and applicable banking practices in carrying out one of the efforts made by banks to protect exporters and importers, including that the bank must apply Good Corporate Governance, apply the principles of Know Your Customer such as the principle of prudence in providing $\mathrm{L} / \mathrm{C}$

\footnotetext{
${ }^{16}$ Interview with Meiria Putri Alsa, Trade Finacing Division, at PT. Bank Maybank Indonesia Tbk Bengkulu Branch, July 28, 2020 at 5.00 pm.
} 
facilities, and apply the principle of the Know Your Employee. Moreover, it is necessary to apply optimal sanctions in the event of a procedural violation.

\section{Suggestion}

Regulations regarding L/C in positive law in Indonesia are strictly regulated according to Government Regulation No.1 of 1982. Meanwhile, the UCP 600 has been widely used for guidelines for the use of $\mathrm{L} / \mathrm{C}$ in many countries. However UCP does not always have binding legal force against $\mathrm{L} / \mathrm{C}$ because UCP is not a product of

Indonesian legislative law nor is it a product of judicial law. UCP is only binding on the $\mathrm{L} / \mathrm{C}$ if the $\mathrm{L} / \mathrm{C}$ contains a clause in the form of a statement that is subject to the UCP. Submission to the new UCP means submission to the implementation of the L/C procedure, it does not necessarily the same with submission to legal issues, especially those that are not regulated in the UCP, such as the problem of fraud and the problem of determining the national law that applies to the $\mathrm{L} / \mathrm{C}$. Therefore, in principle the $\mathrm{L} / \mathrm{C}$ needs to contain a choice of law clause in addition to the submission clause in the UCP. Furthermoew, UCP 600 which regulates L/C has not been fully adopted as a regulation on $\mathrm{L} / \mathrm{C}$, therefore Indonesia must have regulations that firmly support UCP 600 tu fully apply in Indonesia.

References.

L.J Van Apelderon, Pengantar Ilmu Hukum,Pradnya Paramitha,Jakarta, 1990

Huala Adolf, Dasar-Dasar Hukum Kontrak Internasional, Refika Aditama,Bandung 2008

Kasmir, Bank dan Lembaga Keuangan Lainnya, Rajawali Pers, Jakarta, 2013

Ramlan Ginting, Letter of Credit Tinjauan Aspek Hukum \& Bisnis, Penerbit Unversita Trisakti,Jakarta, 2015

Soepriyo Andhibroto, Letter of Credit : Dalam Teori dan Praktek, Dahara Prize, Semarang, 1992

Philipus.M. Hadjon.Perlindungan Hukum Bagi Rakyat di Indonesia. Bina Ilmu, Surabaya, 1987 
Sarah DI Roero, Perlindungan terhadap bank dalam transaksi perdagangan dengan mengunakan sarana letter of credit, Jurnal Ilmiah, Universitas Samratulangi,Manado, 2013,

Amir, MS, Kontrak Dagang Ekspor, Penerbit PPM,Jakarta, 2002

Lukmanul Hakim, Prinsip kehati hatian pada lembaga perbankan dalam pemberian kredit, Jurnal Ilmiah, Universitas Bandar Lampung,Bandar Lampung, 2018

Uswatun Hasanah, Perlindungan Hukum Nasabah, Filosofi, Teori dan Konstruksi, Interpena, Yogyakarta, 2012,

Regulation

Peraturan Pemerintah No.1 tahun 1982 tentang Pelaksanaan Ekspor, Impor dan Lalu Lintas Devisa

Surat Edaran Bank Indonesia No. 26/34/ULN tanggal 17 Desember 1993 yang mengatur mengenai penundukan L/C pada UCP yang berlaku.

Uniform Customers and Practice For Documentary Credits ( UCP ) 600

Undang-Undang Nomor.23 tahun 1999 tentang Bank Indonesia
Undang-Undang Nomor 10 Tahun 1998 Perubahan Undang- undangNomor 7 Tahun 1992 tentang Perbankan

